\title{
Study on the Innovation Path of the Editor Team Construction of Local University Journals
}

\author{
Saihanqiqige \\ Press Agency, Chifeng University \\ Chifeng 024000, China
}

\begin{abstract}
At present, there are many problems in the construction of the journals of local colleges and universities in China, which are mainly reflected in the lack of the post, unreasonable construction of institutions, few funds, and lack of professionals. In order to strengthen the construction of local university journals, we must set up a professional editorial team, make a clear orientation to ourselves, and build the journals of local colleges and universities with the dedicated spirit, professional knowledge, innovative consciousness and reasonable division of labor, laying the foundation for the long-term development of the local university journals.
\end{abstract}

Keywords-Local University Journals; Editor Team; Innovation

\section{INTRODUCTION}

The rapid development of society has led to the construction of local colleges and universities. In recent years, there are more and more local colleges and universities, and almost every university has their own journal, which can show their achievements of scientific research, and colleges and universities can also carry out academic exchanges with other universities through journals. The emergence of journals plays a more and more important role in the development of higher education. However, with the progress of science and technology, university journals become more and more specialized, which also puts forward higher requirements for the construction of editorial team of university journals. Therefore, through the analysis of the current situation of the editorial team of the local university journals and the problems in the journal, the author seeks the innovative path for the construction of the editorial team of the local university journals, hoping to provide reference for the related workers.

\section{THE CURRENT SituAtion OF THE EDITORIAL TEAM OF THE LOCAL UNIVERSITY JOURNALS}

It has to be admitted that in recent years, with the rapid development of local colleges and universities, a good environment has been created for the development of university journals. Whether in scale or quality, university journals have made great progress. The academic exchanges between universities and the display of scientific research achievements also rely more and more on university journals, which means that the local university journals are gradually transforming from the affiliated projects of the construction of local colleges and universities to the main projects. Nowadays, many colleges and universities have realized that, in order to overcome the difficulties encountered by the local university journals, they must regulate the innovation of local university journals, optimize the journal editing system and refine the work process, so as to help the local university journals successfully transform. However, through relevant surveys, it is found that the development of local university journals is not optimistic.

The survey shows that the status of local university journals is very embarrassing at present. The editorial department is at the bottom of the scientific research system of local colleges and universities, and the organizational system of the editorial department of the local university journals is not perfect and can not be solved for a long time. At the same time, the school lacks professional talents related to editing and publishing, the publication funds of the journal are seriously inadequate, and there is no sound staff management system, which can not get attention form school leaders. The relevant staff can not get good salary, and even they are discriminated against, which makes the editing and publishing work of local university journals isolated and marginalized by universities, and the title for editorship can not be conferred, so the related workers can not do the editing the work securely, which has caused great obstacles to the sustainable development of the local university journals.

Through the investigation of the institutions of local university journals, it is found that only a few universities attach importance to the journal edition work, and set up the editorial department of the journal to a ministerial organization, and the other universities randomly name it as scientific research department. In terms of the number of employees, the editorial department of most local universities has only 1-3 staff members, including part-time staff, which is usually edited by a school leader. They do not devote much effort to editing work, so the position of local university journals can be imagined.

The editorial department of the local university journal needs to sort out 400-1200 manuscripts a year. Universities are required to publish 100-500 manuscripts a year, however, the author's level is uneven, and the number of manuscripts that can be used directly is less than $10 \%$. The vast majority of the manuscripts require the staff and their authors to communicate and exchange many times to make changes to meet the requirements of the publication, which also makes 
the editing work more heavy, and the staff feel hard to work on the long-term overload work [1].

Through the investigation of the editors of the local university journals, it is found that only $3 \%$ of the editors who are engaged in the editorial work of the local university journals major in editing, the other editors are all non professional, and most of them have not been trained by the related specialties. They have no specific understanding of the editing work and lack the basis knowledge and experience for editing and publishing, so the editing work proceeds slowly.

The above situation shows that the editorial department of the local university journal is short of professional talents. Improper institutional setting and insufficient funds for publication seriously affect the development of local university journals. The heavy workload of editing also makes the editorial department of local colleges and universities face great pressure. It is obvious that the construction and innovation of the editorial team of the local university journal have been imminent.

\section{THE REASONS FOR THE PROBLEMS OF LOCAL UNIVERSITY JOURNALS}

With the advent of the Internet era, the mechanism of press and publication is constantly being optimized, which brings more difficulties to the development of local university journals. Through the above data, we can see that hindering the development of local university journals is not only structural problems, but also due to the lack of corresponding resources of the editorial staff. The reasons for these problems are mainly in the following aspects.

\section{A. The Status and Role of Local University Journals can not be Correctly Recognized}

Local colleges and universities do not correctly recognize the status and role of the journal, and do not carry out the relevant provisions of the Ministry of Education, which leads to the unfavorable development of the local university journals. The Ministry of Education clearly stipulates the status of the journals of local colleges and universities. As an important part of the scientific research and teaching work of colleges and universities, the editors are also a member of the teaching and scientific research team of the school, and should enjoy the same treatment as the teaching and scientific research personnel.

The editorial department of a university is an academic institution at the ministerial level of the university. The staff engaged in journal editing is also a member of the school teaching and scientific research team. The compilation of teaching and scientific research should include editors, and the editors and teaching and scientific research personnel should be treated equally. At the same time, we should set up corresponding titles to reward excellent editors so that they can take the lead in speeding up the construction of editorial staff in local university journals [2].

\section{B. The Editorial Department of Local University Journals Has Low Status and Vague Position}

The editorial department of the journal of local colleges and universities is a formal publishing institution, which is recognized by the state law, and is guided by the Ministry of Education and the SAPPRFTG (State Administration of Press, Publication, Radio, Film and Television). Its identity is multiple. However, this does not help the editorial work of local university journals, and on the contrary, it leads to the awkward position of journal editors. Therefore, there are two kinds of phenomena in the management of the journal edition: First, it has become a marginal institution in administrative management, without a clear identity position, which leads to the lack of a perfect evaluation system for the editing work and makes the editing work "exist in name only" in the teaching of colleges and universities. Second, the performance assessment of editors is carried out according to the standard of full-time teachers, and the editing work is regarded as a teaching assistant work, which makes the editors lose the motivation of their work. The fundamental source of this result is that the local university administrators do not understand the importance of the journal work correctly and do not carry out the relevant laws and regulations of the Ministry of Education.

\section{The Editorial Position of the Local University Journals Lacks the Corresponding Function}

The survey shows that in most universities, the school leader acts as the chief editor of the journal. Because of various administrative matters, school leaders can not devote too much energy to the editorial work of journals, which leads to the neglect of journals in colleges and universities and also makes the editorial board abandon itself, and do not organize and write manuscripts, which does not play its due role. The director of the editorial department of the journal holds several concurrent posts. They should not only manage the work of the editorial department, but also be responsible for the publication and distribution of the journals. The work tasks are heavy and are several times as many as the other department director, however, the treatment enjoyed is far less than that of other department directors. The reward system is imperfect and the distribution of resources is seriously uneven. This situation makes editorial staff lack internal motivation, reduces the editing efficiency of journal, and affects the overall quality of journal publication.

\section{Editors of Local Journals Lack Professional Knowledge which Hinders the Development of Journals.}

Most of the editors of local university journals are non professionals who have not participated in the related work of the editing. Only about $3 \%$ of the editors are professionals with relevant professional qualifications. Due to the lack of relevant knowledge of editing, they can not adapt to the editing work in the short run, affecting the editing process of journal. Some university leaders even feel that the editorial work is nothing more than writing. Anyone who can manage the staff can be competent. The editors of the journal also get salaries through class. It can be seen that the construction of 
editorial staff has not been attached importance to by universities.

\section{THE INNOVATION PATH OF THE CONSTRUCTION OF THE EDITORIAL TEAM OF THE LOCAL UNIVERSITY JOURNALS}

\section{A. Innovate the Management System of the Journal and Carry out the Responsibility System of Editors in Chief}

The successful development of any work needs the attention of the relevant leaders, and so does the journal work. The editorial department of the journal should be directly managed by the headmaster or the secretary of the Party committee, which is clearly stipulated by the Ministry of Education. Local colleges and universities should increase the funds for the establishment of a journal, set up independent management accounts, conduct data management, improve the quality of the journals, and provide convenience for the construction and development of the journal. The overall quality of a university is mainly reflected in three aspects: The first is the teaching staff, the second is the journal construction, and the third is the university library. It can be seen that university journals occupy an important position in the development of colleges and universities themselves. However, the editorial department of some local university journals has not been established correspondingly. For a long time, there is a lack of publishing funds and a poor working environment, and it is an empty talk to run a good journal. Therefore, the local colleges and universities must innovate the journal management system, fundamentally change the status of the local university journal editing department, and make the journal become a part of the university construction, and play its role in the publicity of the development of the university image.

The professional level and management ability of the editors of local university journals also affect the quality of local university journals. As the general director of journal work, the editor in chief of the journal is the core figure of the journal's work and the university should give full play to the role of them. The Ministry of Education explicitly stipulates that the university journal should implement the responsibility system of chief editor, and also put forward quite high requirements for the editor in chief. The editor in chief must have a higher theoretical level, a strong sense of responsibility, advanced professional skills and decent style. Therefore, local colleges and universities must set up full-time editor posts, strictly enforce the responsibility system of the chief editor, and regularly check the editorial work of the journal [3].

\section{B. Implement the Division of Responsibilities and Build a Professional Editorial Team}

If local universities want to run journals, they must build a professional editorial team. The Ministry of National Education has made clear arrangements for the relevant positions of the editorial department of the journal, and strictly requires the relevant staff to participate in the training organized by the SAPPRFT, and then the relevant personnel can work with relevant professional certificates. Therefore, the school must set up various posts in the editorial department of the journal in accordance with the provisions of the Ministry of Education, and carry out the relevant responsibilities to the individual and build a professional editorial team with knowledge, ability and discipline.

The editor in chief of the journal should comprehensively manage the editorial department of the journal, and take full responsibility for the quality and publication of the journal. They should actively plan the development of the journal construction, formulate the long-term development plan of the journal, report the problems in the editing work to the school leaders in time, and seek the best way to deal with it. At the same time, they should also provide practical and valuable opinions for the better development of journals, and actively safeguard the legitimate rights and interests of editorial departments.

The associate editor should actively organize the editing work, formulate the relevant rules and regulations of the editorial department and improve it, examine the source, cover and format of the manuscript strictly, make statistics on the funds of the editorial department, and actively improve the propaganda work of the editorial department.

The responsible editor should try the manuscript strictly according to the requirements, select the subject with new ideas, submit the high-quality manuscript to the expert review, and be responsible for the payment of the remuneration and the related work expenses.

\section{Realize Innovation of Top-Level Design for Editorial Team Construction of Local University Journals}

In China, all professional and technical titles are certified by the state. It is clearly stipulated that the same grade titles should enjoy equal treatment and status, which helps to train talents and makes them better adapt to their jobs.

The journal edition in local colleges and universities is a compound job. Different from other jobs, the editorial work of journal is of great intensity and long cycle, which requires the staff to have the spirit of bearing hardships and standing hard work, and selfless dedication. Faced with this situation, the traditional teaching method is extremely unscientific and can not motivate editors to work hard. Therefore, it is necessary to pay appropriate remuneration according to the actual workload of the editors and work performance. Only in this way can the editors work harder.

To speed up the construction of local university journals, we must innovate the learning mechanism. The editorial work of the local university journals requires that the staff must have professional knowledge and skills. Only by innovating 
the traditional learning mechanism and training the editors can the staff learn new theories and techniques, meet the needs of the editing work, adapt to the social development and improve the overall quality of local university journals.

\section{CONCLUSION}

To sum up, the editorial team of the journal is the core of the survival and development of the local university journals. The local universities must build a high-quality journal editorial team with the dedicated spirit, professional knowledge, and innovative consciousness. In order to achieve the sustainable development of local university journals, we should make bold innovations in the relevant working mechanism of journal edition.

\section{REFERENCES}

[1] Fusheng Yang: To Run a Journal is to Run a School [J], Journal of Anhui University(Philosophy and Social Sciences), 2000, 1: 105-107.

[2] Meiqun Yang: The Essential Qualities of Young Editors of Sci-Tech Periodicals [J], Acta Editologica, 2010, 6: 547-549.

[3] Yuji Yin: On the Current Situation and Reform Pointcut of Chinese University Journals [J], Journal of Tsinghua University, 2011, 4: 128138. 